\title{
MEKANISME DIVERSI TERHADAP ANAK PECANDU NARKOTIKA DITINJAU DARI UNDANG-UNDANG NOMOR 11 TAHUN 2012 TENTANG SISTEM PERADILAN PIDANA ANAK
}

\author{
Misbahul Ramadhany \\ Ifahda Pratama Hapsari \\ Universitas Muhammadiyah Gresik
}

\begin{abstract}
This research is entitled The Application of Diversion to Children of Narcotics Addicts in terms of Law Number 11 of 2012 concerning the Child Criminal Justice System. Furthermore, the formulation of the problems raised in this thesis are first, how to handle and procedure for giving diversion to children of Narcotics crime perpetrators in Gresik Regency. Second, whether the implementation of Diversion is in accordance with Law Number 11 of 2012 in Gresik Regency. Then the result of the research shows that the diversion mechanism for child offenders of narcotics offenses can be taken on several levels. The first level is the level of investigation in the form of deliberations among them: investigator deliberation, family deliberation and community deliberation. Furthermore, diversion must be carried out at every level of examination, both investigation, prosecution and trial, if the Diversion process is successful before the trial stage, the Investigator and Public Prosecutor will submit the results of the Diversion to the Head of the District Court to make an Determination and based on this Determination the Investigator and Public Prosecutor can issue SP3 (Letter of Order to Stop Investigation) and Decree of Termination of Prosecution. If the Diversion process succeeds in the trial stage, the Minutes and results of the Diversion shall be submitted to the Head of the District Court to make a decision on the termination of the case as for the legal action taken against the child who is a drug addict who fails to diversify, namely in the form of guidance.
\end{abstract}

Keywords: Diversion; Children; Narcotics; Criminal Justice System

\section{Pendahuluan}

Kejahatan tidak hanya dilakukan oleh Orang Dewasa melainkan sudah merambah perilaku Anak untuk melakukan kejahatan. Perbuatan sederhana dari kejahatan yang dilakukan oleh Anak adalah perbuatan kejahatan perampasan barang-barang milik teman sebayanya. Bilamana kita mampu untuk mencermati, Anak merupakan subyek hukum dan aset bangsa, sebagai bagian dari generasi muda anak berperan sangat strategis sebagai generasi penerus suatu bangsa. Dalam konteks Indonesia, anak adalah penerus cita-cita perjuangan suatu bangsa. "Peran strategis ini telah disadari oleh masyarakat Internasional untuk melahirkan sebuah konvensi yang intinya menekankan posisi anak sebagai makhluk manusia yang harus mendapatkan perlindungan atas hak-hak yang dimilikinya. Kenakalan anak sudah tidak bisa dipandang lagi sebagai kenakalan biasa, anak-anak banyak melakukan perbuatan yang tergolong tindak pidana, seperti : mencuri, membawa senjata tajam, terlibat perkelahian, terlibat penggunaan narkoba, dan lain-lain. Namun demikian, anak yang melakukan tindak pidana dan perbuatan yang dilarang oleh hukum, harus ditafsirkan sebagai ketidakmampuan akal (pikiran), fisik (badan) atau moral dan mentalitas yang ada pada diri anak yang ditentukan oleh nilai kodrat. 
Penyimpangan tingkah laku atau perbuatan melanggar hukum yang dilakukan oleh Anak disebabkan oleh berbagai faktor antara lain adanya dampak negatif dari perkembangan pembangunan yang cepat, arus globalisasi di bidang komunikasi dan informasi, kemajuan ilmu pengetahuan dan teknologi serta perubahan gaya dan cara hidup sebagai orang tua, telah membawa perubahan sosial yang mendasar dalam kehidupan masyarakat yang sangat berpengaruh terhadap nilai dan perilaku anak. Selain itu, Anak yang kurang atau tidak memperoleh kasih sayang, asuhan dan bimbingan dan pembinaan dalam pengembangan sikap perilaku penyesuain diri, serta pengawasan dari orang tua, wali atau orang tua asuh akan mudah terseret dalam arus pergaulan masyarakat dan lingkungannya yang kurang sehat dan merugikan perkembangan pribadinya.

Atas pengaruh dari keadaan sekitarnya, maka acapkali Anak ikut melakukan tindak pidana. Hal itu dapat disebabkan oleh bujukan, spontanitas atau sekedar ikutikutan. Meskipun demikan tetap saja hal itu merupakan tindakan pidana. Namun demi pertumbuhan dan perkembangan mental Anak, perlu diperhatikan pembedaan perlakuan di dalam hukum acara dan ancaman pidana. Menurut Pasal 45 Kitab Undang-Undang Hukum Pidana (selanjutnya disingkat dengan KUHP) bahwa anak yang belum dewasa apabila belum berumur 16 tahun. Apabila anak terlibat dalam perkara pidana hakim boleh memerintahkan agar tersangka di bawah umur tersebut dikembalikan kepada orang tuanya, walinya, dan pemeliharaanya dengan tidak dikenakan suatu hukuman atau memerintahkan supaya diserahkan kepada pemerintah dengan tidak dikenakan suatu hukuman.

Pembedaan perlakuan dan ancaman yang diatur dalam Undang-Undang Nomor 23 Tahun 2002 tentang Perlindungan Anak (untuk selanjutnya disebut UU Perlindungan Anak) dimaksudkan untuk melindungi dan mengayomi anak tersebut agar dapat menyongsong masa depan yang panjang. Ketentuan Pasal 1 angka 1 UU Perlindungan Anak, menyebutkan yang dimaksud dengan Perlindungan Anak adalah segala kegiatan untuk menjamin dan melindungi anak dan hak-haknya agar dapat hidup, tumbuh, berkembang dan berpartisipasi, secara optimal sesuai dengan harkat dan martabat kemanusiaan, serta mendapat perlindungan dari kekerasan dan diskriminasi, sedangkan dalam ketentuan Pasal 1 angka 15 UU Perlindungan Anak dijelaskan tentang yang dimaksud dengan Perlindungan Khusus adalah perlindungan yang diberikan kepada anak dalam situasi darurat, anak berhadapan dengan hukum. Selain itu pembedaan tersebut dimaksudkan untuk memberi kesempatan kepada anak melalui pembinaan akan diperoleh jati dirinya untuk menjadi manusia yang mandiri, bertanggung jawab,dan berguna bagi diri, keluarga, masyarakat, bangsa dan negara.

Di Indonesia saat ini, bentuk perlindungan hak-hak anak telah dituangkan dalam beberapa peraturan salah satunya adalah undang-undang seperti UU Perlindungan Anak, Undang-Undang Nomor 11 Tahun 2012 tentang Sistem Peradilan Anak (untuk selanjutnya disebut UU SPPA), Undang-Undang Nomor 33 Tahun 1999 tentang HAM (untuk selanjutnya disebut UU HAM), dan Hukum Internasional tentang Konvensi HakHak Anak.

Dalam melaksanakan pemeriksaan terhadap anak sebagai pelaku tindak pidana haruslah sesuai dengan ketentuan UU SPPA serta harus diperhatikan tentang tujuan peradilan anak yaitu melakukan koreksi dan rehabilitasi sehingga anak dapat kembali ke 
kehidupan yang normal dan bukan mengakhiri harapan dan potensi masa depannya. Yang penting adalah bagaimana cara mendidik anak dalam proses penyelesaian konflik dengan hukum. Hal ini tentunya berpengaruh terhadap cara penanganan kasus anak. Dalam praktek, hukuman yang diajtuhkan kepada anak yang melakukan tindak pidana lebih ringan dibandingkan dengan hukuman untuk orang dewasa. Hal ini sudah sesuai dengan ketentuan perundangan-undangan yang hanya menentukan pidana bagi anak adalah setengah dari hukuman orang dewasa. Hukuman ini dianggap sudah cukup sebagai bentuk pendidikan bagi anak agar tidak mengulang lagi perbuatan yang sama dikemudian hari, dan tetap dapat berkembang sebagaimana anak-anak lain seusianya. Meskipun demikian ada perbedaan putusan yang dijatuhkan terhadap perkara-perkara tertentu yang melibatkan anak dibawah umur.

Seperti halnya orang dewasa, anak sebagai pelaku tindak pidana juga akan mengalami proses hukum yang identik dengan orang dewasa yang melakukan tindak pidana, arti kata identik disini mengandung arti "hampir sama", yang berbeda hanya lama serta cara penanganannya. Lama penahanan pada tingkat penyidikan untuk anak-anak di tahap pertama adalah 7 hari dan jika proses penyidikan belum selesai dapat di perpanjang selama 8 hari, jadi totalnya adalah 15 hari. Untuk orang dewasa pada proses penyidikan tahanan dewasa untuk tahap pertama di tahan selama 20 hari dan dapat di perpanjang paling lama 40 hari jadi totalnya adalah 60 hari. Di samping itu, penanganan oleh petugas Polri atau penyidik terhadap anak-anak tidak sama dengan penyidik untuk orang dewasa, hal ini di atur di dalam Pasal 33 UU SPPA.

Tindakan diversi dapat dilakukan oleh pihak kepolisian, kejaksaan, pihak pengadilan maupun pembina lembaga pemasyarakatan. Penerapan diversi di semua tingkatan ini diharapkan mengurangi efek negatif (negative effect) keterlibatan anak dalam proses peradilan tersebut. Terkait dengan itu, dalam mengakomodir prinsip-prinsip perlindungan anak terutama prinsip non diskriminasi yang mengutamakan kepentingan terbaik bagi anak dan hak untuk hidup, kelangsungan hidup dan perkembangan anak, UU SPPA yang merupakan pergantian terhadap Undang-undang Nomor 3 Tahun 1997 tentang Pengadilan Anak (untuk selanjutnya disebut UU No. 3 Tahun 1997) telah mengatur secara tegas mengenai Keadilan Restoratif dan Diversi yang dimaksudkan untuk menghindari dan menjauhkan anak dari proses peradilan sehingga dapat menghindari stigma terhadap anak yang berhadapan dengan hukum dan si anak dapat kembali ke dalam lingkungan sosial secara wajar. Oleh karena itu sangat diperlukan peran serta semua pihak dalam mewujudkan hal tersebut.

Dalam Pasal 1 angka 7 UU SPPA disebutkan Diversi adalah pengalihan penyelesaian perkara Anak dari proses peradilan pidana ke proses di luar peradilan pidana. UU SPPA telah mengatur tentang Diversi yang berfungsi agar anak yang berhadapan dengan hukum tidak terstigmatisasi akibat proses peradilan yang harus dijalaninya. Penggunaan mekanisme diversi tersebut diberikan kepada para penegak hukum (polisi, jaksa, hakim, lembaga lainnya) dalam menangani pelanggar-pelanggar hukum yang melibatkan anak tanpa menggunakan pengadilan formal. Penerapan Diversi tersebut dimaksudkan untuk mengurangi dampak negatif keterlibatan anak dalam suatu proses peradilan. 
Pelaksanaan Diversi juga harus dengan persetujuan anak sebagai pelaku kejahatan, orang tua atau walinya serta memerlukan kerja sama dan peran masyarakat sehubungan dengan adanya program seperti: pengawasan, bimbingan, pemulihan, serta ganti rugi kepada korban. Proses Diversi wajib memperhatikan : kepentingan korban, kesejahteraan dan tanggung jawab Anak, penghindaran stigma negatif, penghindaran pembalasan, keharmonisan masyarakat, dan kepatutan, kesusilaan, dan ketertiban umum.

\section{Metode}

Penelitian ini menggunakan metode penelitian hukum yang bertujuan untuk mencarai pemecahan atas isu hukum serta permasalahan yang timbul di dalamnya, sehingga hasil yang Akan dicapai kemudian adalah memberikan preskripsi mengenai apa yang seyogyanya atas isu yang diajukan.

\section{Hasil Penelitian dan Pembahasan}

Secara konseptual, Diversi adalah suatu mekanisme yang memungkinkan Anak dialihkan dari proses peradilan menuju proses pelayanan sosial. Dengan demikian, Diversi juga bermakna suatu upaya untuk mengalihkan Anak dari proses yustisial menuju proses non-yustisial. Upaya untuk mengalihkan proses peradilan pidana Anak menuju proses non-peradilan didasarkan atas pertimbangan, bahwa keterlibatan Anak dalam proses peradilan pada dasarnya telah melahirkan stigmatisasi. Berbagai dampak negatif akibat Anak bersentuhan dengan dengan dunia peradilan menjadi petimbangan utama dimungkinkannya Diversi terhadap penyelesaian kejahatan yang dilakukan oleh Anak. Peradilan Anak juga merupakan upaya untuk mewujudkan kesejahteraan Anak, sehingga pelaksanaannya harus sejauh mungkin menghindarkan Anak dari setiap pemidanaan yang bersifat punitif.

Undang-Undang Sistem Peradilan Pidana Anak menekankan bahwa Diversi adalah wajib diupayakan oleh para penegak, ini terlihat dari Pasal 7 ayat (1) yang mengatakan bahwa pada tingkat penyidikan, penuntutan, dan pemeriksaan perkara Anak di pengadilan negeri wajib diupayakan Diversi. Dari uraian pasal tersebut, terlihat bahwa dari tingkat kepenyidikan sudah diterapkan kebijakan yang bersifat non-penal terhadap Anak sebagai pelaku tindak pidana narkotika. Merujuk pada ketentuan yang terdapat di dalam Pasal 7 ayat (2) Undang-Undang Sistem Peradilan Pidana Anak, Diversi dilaksanakan dalam hal tindak pidana yang dilakukan dengan kriteria sebagai berikut: diancam dengan pidana penjara di bawah 7 (tujuh) tahun; dan Bukan merupakan pengulangan tindak pidana.

Melalui ketentuan di atas maka dapat dilihat bahwa tindak pidana penyalahgunaan narkotika khususnya yang dilakukan oleh Anak memenuhi kriteria di atas, karena berdasarkan ketentuan Pasal 127 Undang-undang Narkotika, ancaman tertinggi untuk pelaku tindak pidananya (dewasa) adalah 4 Tahun, dan bila ancaman pidana tersebut dikaitkan dengan Anak sebagai pelaku tindak pidananya, berdasarkan ketentuan Pasal 79 Undang-Undang Sistem Peradilan Pidana Anak, maka Pidana pembatasan kebebasan yang dijatuhkan terhadap Anak paling lama 1/2 (satu perdua) dari 
maksimum pidana penjara yang diancamkan terhadap orang dewasa. Hal ini mengakibatkan ancaman maksimal yang diberikan terhadap Anak pelaku tindak pidana penyalahgunaan narkotika adalah 2 tahun.

Diversi sebagai usaha mengajak masyarakat untuk taat dan menegakan negara, pelaksanaanya tetap mempertimbangkan rasa keadilan sebagai prioritas utama disamping pemberian kesempatan kepada pelaku untuk menempuh jalur non pidana seperti ganti rugi, kerja sosial atau pengawasan orang tuanya. Diversi tidak bertujuan mengabadikan dan keadailan Sama sekali, Akan tetapi berusaha memakai unsur pemaksaan seminimal mungkin untuk membuat orang mentaati.

Ada 2 (dua) bentuk mekanisme pelaksanaan Diversi oleh kepenyidikan, yaitu:

a. Tahapan Musyawarah Masyarakat

Pihak yang terlibat dalam proses ini adalah pelaku/anak, penyidik, orangtua/wali, pembimbing kemasyarakatan (Bapas), BNN (Badan Narkotika Nasional) dan masyarakat (tokoh masyarakat atau dari pihak sekolah). Jenis tindak pidana yang dapat diselesaikan melalui musyawarah masyarakat ini adalah tindak pidana yang ancaman pidananya di bawah 7 (tujuh) tahun dan bukan pengulangan tindak pidana.

Pertemuan ini dimulai dengan memberikan kesempatan kepada pelaku untuk memaparkan bagaimana tindak pidana itu dilakukan dan atas dasar apa tindak pidana itu dilakukan. Pihak pelaku yang melakukan pemaparan sangat mengharapkan pihak korban untuk dapat menerima dan memahami kondisi dan penyebab mengapa pihak pelaku melakukan tindak pidana yang menyebabkan kerugian pada korban.

Selanjutnya dalam penjelasan pelaku juga memaparkan tentang bagaimana dirinya bertanggung jawab terhadap korban dan masyarakat atas perbuatan yang telah dilakukannya. Selama pihak pelaku memaparkan tentang tindakan yang telah dilakukannya dan sebab-sebab mengapa sampai tindakan tersebut dilakukan pelaku, pihak yang lain terutama korban wajib mendengarkan dengan teliti penjelasan pelaku. Untuk selanjutnya pihak korban dapat memberikan tanggapan atas penjelasan pelaku. Korban menceritakan pengalaman yang dialaminya akibat kejahatan tersebut dan apa yang menjadi kerugian fisik, emosional, dan materi pada dirinya.

Selain itu juga hadir pihak masyarakat yang mewakili kepentingan masyarakat. Wakil masyarakat tersebut memberikan gambaran tentang kerugian yang diakibatkan oleh telah terjadinya tindak pidana yang dilakukan oleh pelaku. Dalam paparannya tersebut masyarakat mengharapkan agara pelaku melakukan suatu perbuatan atau tindakan untuk memulihkan kembali keguncangan/kerusakan yang telah terjadi karena perbuatannya. Di sinilah terjadi suatu ikatan sosial antara pelaku tindak pidana dengan masyarakat.

\section{b. Kesepakatan Diversi}

Musyawarah Diversi dicatat dalam berita acara diversi dan ditandatangani oleh fasilitator diversi dan panitera/panitera pengganti. Kemudian kesepakatan diversi ditandatangani oleh para pihak dan dilaporkan kepada ketua pengadilan oleh fasilitator diversi. Ketua pengadilan mengeluarakan penetapan kesepakatan diversi berdasarkan kesepakatan diversi. Selanjutnya, ketua pengadilan dapat mengembalikan kesepakatan diversi untuk diperbaiki oleh fasilitator diversi apabila tidak memenuhi syarat, selambat- 
lambatnya dalam waktu tiga hari. Setelah menerima penetapan dari ketua pengadilan, hakim menerbitkan penetapan penghentian pemeriksaan perkara.

Dalam hal kesepakatan diversi tidak dilaksanakan sepenuhnya oleh pihak berdasarkan hasil laporan dari pembimbing kemasyarakatan balai pemasyarakatan, hakim melanjutkan pemeriksaan perkara sesuai dengan hukum aara peradilan pidana anak. Dalam menjatuhkan putusan, hakim wajib mempertimbangkan pelaksanaan sebagian kesepakatan diversi.

Fasilitator diversi tidak dapat dikenai pertanggungjawaban pidana maupun perdata atas isi kesepakatan diversi. Lebih lanjut, penetapan ketua pengadilan atas kesepakatan diversi memuat pula penentuan status barang bukti yang telah disita dengan memperhatikan kesepakatan diversi.

Selanjutnya, dalam konteks pembinaan terhadap anak, kepentingan terbaik anak harus menjadi pertimbangan utama, bukan prosedur formal atas Nama kepastian. Tak dapat dipungkiri, bahwa berkaitan dengan proses penanganan perkara anak seringkali muncul pro dan kontra terhadap langkah-langkah yang diambil. Di satu sisi ada kelompok masyarakat yang menghendaki agar anak yang terlibat dalam kejahatan ditangani secara tegas, untuk meberikan pelajaran bagi anak, tetapi di sisi lain, juga ada kelompok masyarakat yang menghendaki kearifan dalam menyelesaikan perkara yang melibatkan anak.

Patut kiranya dikemukakan berbagai ukuran normatif yang menjadi dasar sebagaimana sebaiknya anak meproleh perlakuan dalam rangka pembinaan anak. Untuk keperluan tersebut berikut ini dikemukakan berbagai ketentuan yang mengatur tentang bagaimana sebaiknya perlakuan terhadap anak diberikan khususnya ketentuan-ketentuan dalam perundang-undangan yang dipandang sebagai insturmen yang lebih bersifat oprasional. Namun demikian, untuk melihat sejauhmana perundang-undangan yang ada telah mengakomodasi berbagai instrument internasional akan terlebih dahulu dikemukakan prinsip dasar yang terdapat dalam instrument internasional yang dimaksud.

Konvensi hak-hak anak 1989 memuat prinsip-prinsip yang menjadi pijakan dalam pembinaan anak, yang menyatakan bahwa: The child, by the reason of his phisycal and mental immatury, needs special safeguards and care, including appropriate legal, before as wellas other birth. Whereas the child, by the reason of his physical and mental immatury, needs special safeguards and care, including appropriate legal protection, before as well as after birth. (Anak karena ketidakmatangan jasmani dan mentalnya, memerlukan pengamanan dan pemeliharaan khusus termasuk perlindungan yang layak, sebelum dan sesudah kelahirannya; mangingat alasan karena ketidakmatangan jasmani dan mental dari anak, maka memerlukan pengamanan dan pemeliharaan khusus termasuk perlindungan yang layak, sebelum dan sesudah kelahirannya).

Berdasarkan prinsip-prinsip tersebut di atas, maka dalam konvensi hk-hak anak 1989 terdapat beberapa pokok-pokok pikiran, antara lain:

1. Pengakuan bahwa anak demi perkembangan jiwanya yang penuh dan harmonis, harus tumbuh berkembang dalam lingkungan keluarga, dalam suasana bahagia, penuh kasih sayang, dan pengertian.

2. Sebagaimana ketentuan dalam deklarasi hak anak, anak dengan berbagai alasan kekurangmatangan fisik dan mentalnya, membutuhkan perhatian dan 
penjagaan khusus termasuk kebutuhan akan perlindungan baik sebelum maupun sesudah kelahirannya.

3. Dengan tidak mengabaikan pentingnya peranan nilai-nilai tradisi dan kultural setiap bangsa, sejauh menyangkut perlindungan dan perkembangan harmonis anak.

Bertolak dari muatan subtansial dalam konvensi hak-hak anak 1989 tersebut maka dapat dikemukakan, bahwa dalam proses pembinaan anak lingkungan keluargnya haruslah memberikan ruang yang cukup baik secara jasmani maupun rohani yang memungkinkan anak tumbuh dan berkembang secara sehat dalam suasana yang bahagia dan penuh pengertian. Sikap penuh pengertian mengandung makna, bahwa lingkungan keluarga harus memahami kebutuhan/kepentingan anak dalam rangka pertumbuhan jiwa dan jasmaninya secara sehat. Pengakuan secara sadar terhadap kepentingan dan kebutuhan dasar anak menjadi kunci dalam melakukan pembinaan anak.

Dalam konteks hukum peran orang tua dalam penanggulangan penyalahgunaan narkotika dapat dilakukan dalam bentuk pengalihan pertanggungjawaban pidana. Mekanisme, bentuk dan pelaksanaan pengalihan pertanggungjawaban pidana tersebut perlu diatur sedemikian rupa, sehingga pengalihan pertanggungjawaban pidana ini tidak hanya dilihat semata-mata sebagai pintu maaf bagi anak. Kesadaran anak perlu dibangun melalui pengalihan pertanggungjawaban pidana tersebut, sehingga anak dapat memahami, bahwa apa yang dilakukannya telah menimbulkan beban pada orang lain. Meskipun tidak dapat diberlakukan terhadap semua jenis tindak pidana penyalahgunaan narkotika yang dilkukan oleh anak, dalam hal ini misalnya dapat ditentukan hanya untuk jenis tindak pidana narkotika yang tidak terlalu berat, tetapi mekanisme alternatif untuk mengalihkan pertanggungjawaban pidana anak pada orang tua akan memberikan dua keuntungan sekaligus, yaitu sebagai berikut:

1. Mekanisme pengalihan pertanggungjawaban pidana dalam hal anak melakukan tindak pidana narkotika kepada orang tua akan mengeleminasi sikap masa bodoh orang tua terhadap kewajiban membina anak. Dengan demikian, pengalihan pertanggungjawaban pidana anak terhadap orang tua di dasarkan pada pemikiran, bahwa ada kewajiban hukum orang tua untuk membina anak. Dengan demikian, kegagalan orang tua di dalam membina anak diminta pertanggungjawabannya. Rasionalitas pengalihan pertanggungjawaban pidana anak kepada orang tua adalah oleh karena adanya kewajiban orang tua untuk mendidik anak di satu sisi, dan adanya hak anak untuk mendapatkan proses pendidikan orang tua di sisi yang lain. Mekanisme pengalihan pertanggungjawaban pidana anak kepada orang tua dapat dipandang sebagai pengkhususan dari prinsip umum dalam hukum pidana, yaitu prinsip individualisasi pidana. Dengan demikian, mekanisme pengalihan pertanggungjawaban pidana anak kepada orang tua tidak harus dimaknai sebagai penyimpangan terhadap prinsip-prinsip dalam hukum pidana.

2. Mekanisme pengalihan pertangggungjawaban pidana anak kepada orang tua juga memberikan keuntungan kepada anak, dimana anak akan terhindar dari berbagai dampak negatif penerapan pidana, khususnya penerapan pidana perampasan kemerdekaan. Selain itu, yang terpenting adalah mekanisme pengalihan pertannggungjawaban pidana anak kepada orang tua akan menghindarkan anak 
dari pengalaman dalam proses peadilan pidana. Disadari atau tidak, realitas menunjukkan, bahwa pengalaman seorag anak dalam proses peradilan justru menjadi sanksi psikologis yang dirasakan lebih berat dari pada sanksi yang dijatuhkan hakim itu sendiri. Pengalaman seorang anak dalam proses peradilan pidana seringkali merupakan sanksi psikologis yang justru akan menimbulkan trauma psikologis yang berkepanjangan.

Terdapat beberapa pendapat, yang menyatakan bahwa anak hingga melakukan tindak pidana bersumber pada keadaan keluarga atau karena perlakuan orang tua yang salah asuh, sehingga orang tua harus bertanggung jawab atas kondisi tersebut. Simanjuntak menyatakan bahwa sebab yang paling banyak mengakibatkan kejahatan barangkali orang tua. Menuntut orang tua memang universal dan patologis, untuk itu perlu di buat peraturan yang mewajibkan orang tua bertanggung jawab atas salah asuh terhadap anak-anaknya. Demikian juga pendapat Hunding yang dikutif Sudarto, menyebutkan, bahwa suatu penuntutan pidana dilakukan apabila perbuatan dari pelaku muda itu jelas berpusat pada pelanggaran norma atau tindak pidana, tetapi apabila perbuatan itu merupakan gejala dari suatu keadaan yang sebenarnya tidak dikehendaki, suatu hal yang kebetulan, salah satu dari sekian banyak bentuk perbuatan yang jelek, yang bersumber pada keadaan keluarga, maka akan lebih baik apabila ditempuh jalan pemberian tindakan secara hukum yang berupa penyerahan kepada Negara untuk dibina. Sependapat dengan hal tersebut, Made Sadhi Astuti, yang menyatakan, bahwa apabila anak melakukan tindak pidana yang penyebabnya bersumber pada keadaan keluarga, maka hasilnya akan lebih baik apabila anak tidak di jatuhi pidana, tetapi menyerahkan kepada Negara untuk dibina. Hal ini karena pada dasarnya orang tua ikut bertanggungjawab atas salah asuh anak-anaknya.

Terhadap pendapat-pendapat tersebut di atas maka penulis kurang sependapat, dimana terhadap anak yang melakukan tindak pidana yang penyebabnya bersumber dari keluraga, bukan diserahkan kepada Negara, akan tetapi dilihkan dengan menyerahkan pertannggungjawabannya tetap kepada orang tua, sehingga dapat dipahami bahwa apa yang dilakukan oleh anaknya telah menimbulkan beban bagi orang lain dan peran orang tua dalam membina anak akan lebih optimal. Pengalihan pertanggungjawaban pidana anak kepada orang tua juga bertolak dari bingkai yuridis dalam Pasal 9 UU Nomor 4 tahun 1979 Tentang Tanggung Jawab Orang Tua adalah yang pertama-tama bertanggungjawab atas terwujudnya kesejateraan anak baik secara jasmani, rohani maupun sosial.

Dengan demkian ketika anak teraniaya secara sosial oleh karena misalnya menjadi tersangka/terdakwa orang tua juga bertannggugjawab terhadap mereka. Logikanya sangat sederhana, ketika orang tua gagal menjalankan kewajibannya kepada anak untuk menjamin kesejahteraan secara sosial, maka ia bertanggungjawab terhadap kegagalannya itu.

\section{Kesimpulan}

Berdasarkan hasil penelitian dan analisis yang dilakukan melalui pengkajian sebagaimana telah diuraikan dalam bab-bab sebelumnya, maka penelitian ini ini sampai 
kepada kesimpulan bahwa mekanisme diversi terhadap anak pelaku tindak pidana narkotika dapat di tempuh dalam beberapa tingkatan. Tingkatan yang pertama yaitu pada tingkatan penyidikan yang berupa musyawarah-musyawarah diantranya: musyawarah penyidik, musyawarah keluarga dan musyawarah masyarakat. Selanjutnya, diversi wajib dilaksanakan dalam setiap tingkatan pemeriksaan, baik penyidikan, penuntutan dan pemeriksaan dipersidangan, apabila proses Diversi berhasil sebelum tahap persidangan maka Penyidik dan Penuntut Umum menyampaikan hasil Diversi kepada Ketua Pengadilan Negeri untuk dibuat Penetapan dan berdasarkan Penetapan tersebut Penyidik dan Penuntut Umum dapat menerbitkan SP3 (surat Perintah Penghentian Penyidikan) dan Surat Ketetapan Penghentian Penuntutan (SKPP). Apabila proses Diversi berhasil dalam tahap persidangan maka Berita Acara dan hasil Diversi diserahkan kepada Ketua Pengadilan Negeri untuk dibuat Penetapan penghentian perkara tersebut Adapun upaya hukum yang di tempuh terhadap anak pecandu narkotika yang gagal diversi yaitu berupa pembinaan. Dalam proses pembinaan anak lingkungan keluargnya haruslah memberikan ruang yang cukup baik secara jasmani maupun rohani yang memungkinkan anak tumbuh dan berkembang secara sehat dalam suasana yang bahagia dan penuh pengertian. Sikap penuh pengertian mengandung makna, bahwa lingkungan keluarga harus memahami kebutuhan/kepentingan anak dalam rangka pertumbuhan jiwa dan jasmaninya secara sehat. Pengakuan secara sadar terhadap kepentingan dan kebutuhan dasar anak menjadi kunci dalam melakukan pembinaan anak.

\section{Daftar Pustaka}

\section{Buku-Buku}

Achmad, Ruben. Upaya Penyelesaian Masalah Anak yang Berkonflik dengan Hukum di Kota Palembang, Jurnal Simbur Cahaya Nomor 27 Tahun X, 2005.

Adi, Kusno. Diversi Sebagai Upaya Alternatif Penanggulangan Tindak Pidana Narkotika Oleh Anak. Malang: UMM Press. 2009.

Atmasasmita, Romli. Peradilan Anak di Indonesia. Bandung: Mandar Maju. 1997.

Gosita, Arif. 2004. Masalah Korban Kejahatan. Jakarta: Bhuana Ilmu Populer. 2004.

Gultom, Maidin. Perlindungan Hukum Terhadap Anak dalam Sistem Peradilan Pidana Anak di Indonesia. Bandung: Refika Aditama. 2008.

Huraerah, Abu, Kekerasan Terhadap Anak, Nuansa Cendekia, Bandung, 2012.

Marlina. Pengantar Konsep Diversi dan Restorative Justice dalam Hukum Pidana. Medan: USU Press. 2011.

Marzuki, Peter Mahmud. Penelitian Hukum. Jakarta: Penerbit Kencana Media Group. 2000. 
Prakoso, Abintoro. Pembaruan Sistem Peradilan Pidana Anak. Erlangga, Surabaya. 2013.

Wahyudi, Setya. Implementasi Ide Diversi Dalam Pembaruan Sistem Peradilan Pidana Anak Di Indonesia. Yogyakarta: Genta Publishing. 2011.

Ruba'I, Masruchin dkk.Hukum Pidana. Malang: Media Nusa Creative. 2015.

Nuraeny, Henny. Tindak Pidana Perdagangan Orang, Kebijakan Hukum Pidana Dan Pencegahannya, Cetakan Pertama. Jakarta: Sinar Grafika, 2011.

Nasution, Bahder Johan. Negara Hukum Dan Hak Asasi Manusia, Mandar Maju, Bandung, 2012

Wibowo, Adhi Perlindungan Hukum Korban Amuk Massa, Sebuah Tinjauan Viktimologi, Thafa Media, Yogyakarta.2013

\section{Peraturan Perundang-Undangan}

Undang-Undang Dasar Negara Republik Indonesia Tahun 1945

Undang-Undang Negara Republik Indonesia Nomor 39 Tahun 1999 Tentang Hak Asasi Manusia (Lembaran Negara Tahun 1999 Nomor 165, Tambahan Lembaran Negara Republik Indonesia Nomor 3886)

Undang-Undang Negara Republik Indonesia Nomor 23 Tahun 2002 Tentang Perlindungan Anak (Lembaran Negara Tahun 2002 Nomor 109, Tambahan Lembaran Negara Republik Indonesia Nomor 4235)

Undang-Undang Negara Republik Indonesia Nomor 35 Tahun 2009 Tentang Narkotika (Lembaran Negara Tahun 2009 Nomor 143, Tambahan Lembaran Negara Republik Indonesia Nomor 5062)

Undang-Undang Negara Republik Indonesia Nomor 11 Tahun 2012 Tentang Sistem Peradilan Pidana Anak (Lembaran Negara Tahun 2012 Nomor 153, Tambahan Lembaran Negara Republik Indonesia Nomor 5332)

Peraturan Mahkamah Agung Republik Indonesia Nomor 4 Tahun 2014 Tentang Pedoman Pelaksanaan Diversi Dalam Sistem Peradilan Anak 